\title{
Kabul ve Adanmışlık Terapisi (ACT) Üzerine Bir Derleme Çalışması
}

\author{
DOI: $10.26466 /$ opus.741907
}

\author{
Aykut Kul *-Fulya Türk** \\ *Arş. Gör., Gaziantep Üniversitesi, Eğitim Fakültesi, Gaziantep/Türkiye \\ E-Posta: aykutkul@gantep.edu.tr \\ ORCID: 0000-0002-2851-2222 \\ *Doç. Dr., Gaziantep Üniversitesi, Eğitim Fakültesi, Gaziantep/Türkiye \\ E-Posta: fulyaturk@gantep.edu.tr \\ ORCID: $\underline{0000-0003-1896-8418}$
}

\section{Öz}

Kabul ve Adanmışlık Terapisi (Acceptance and Commitment Therapy-ACT) davranışçı terapilerin üçüncü dalga yaklaşımları arasında yer alan, felsefi temelleri İşleosel Bağlamsalcılık kuramına, kuramsal temeli ise dil-biliş ilişkisi üzerine temellendirilen İlişkisel Çerçeve kuramına dayanan, radikal davranışçı ve süreç temelli bir psikoterapi modelidir. ACT, bireylerin kontrolü dışında gerçekleşen ve onları olumsuz etkileyen olay ya da durumları olduğu gibi kabul etmeleri ve yaşamların daha anlamlı ve zengin kılacak davranışları sürdürmelerine yardımo olmayı hedeflemektedir. Bu derleme çalışmasının amacı ACT'ı genel hatlarıyla ele almak ve tanıtmaktır. Bu bağlamda, öncelikle Davranışçı Terapilerin ü̧̈ kuşağı incelenecek ve Kabul ve Adanmışlık Terapisinin ortaya çıkış süreci ele alınacaktır. Ardından ACT'ın kurucusu olan Steven C. Hayes'in hayatına yer verilecek, bu kısımdan sonra ACT'ın felsefi temelini oluşturan İşlevsel Bağlamsalculık ve kuramsal zeminini oluşturan İlişkisel Çerçeve Kuramı üzerinde durulacaktır. Ardından kuramın insan doğasına bakışı, temel kavramları ve terapi süreci incelenecek sonrasında ise ACT'ın etkililiğine dair yapılan çalışmaların sonuçları incelenecek ve son olarak ACT'a yapılan eleştirilere yer verilerek çalışma sonlandırılacaktır.

Anahtar Kelimeler: Kabul ve Adanmışlık Terapisi, Psikolojik Esneklik, İlişkisel Çerçeve Kuramı, Davranışçılık 


\title{
A Review on Acceptance and Commitment Therapy (ACT)
}

\begin{abstract}
Acceptance and Commitment Therapy (ACT) is a radical behavioral and process-based psychotherapy model, which is among the third wave approaches of behavioral therapies, whose philosophical foundations are based on the Functional Contextualism theory, and its theoretical basis on the Relational Frame Theory based on the language-cognition relationship. ACT aims to help individuals accept the events or situations that occur out of their control and affect them negatively, and to maintain behaviors that will make their lives more meaningful. The purpose of this review is to discuss and present ACT in general terms. In this context, first, three generations of Behavioral Therapies will be examined and the emergence process of Acceptance and Commitment Therapy will be discussed. Then, the life of Steven C. Hayes, the founder of ACT, will be included, and this section will focus on the Functional Contextualism and the Relational Frame Theory that forms the theoretical basis of ACT. Then, the approach of the theory to human nature, its basic concepts and the process of therapy will be examined. Afterwards, the results of the studies on the effectiveness of ACT will be examined and finally the study will be terminated by including the criticisms made on ACT.
\end{abstract}

Keywords: Acceptance and Commitment Therapy, Psychological Flexibility, Relational Frame Theory, Behaviorism 


\section{Giriş}

"İyi hissetmek", her daim mutluluğun peşinde olmak, sürekli olumlu duyguları deneyimleme arzusu ve olumsuz duygulardan kaçınmak günümüzde insanların en temel yaşam hedeflerinden biri haline gelmiş durumdadır. Ancak insanın hayatında yalnızca olumlu duygulara sahip olması pek mümkün görünmemekle birlikte acı, insan hayatının kaçınılmaz bir parçasıdır. Bu noktada Kabul ve Adanmışlık Terapisi (Acceptance and Commitment Therapy$\mathrm{ACT}$ ), isminden de anlaşılabileceği üzere bireyi kişisel kontrolü dışındakileri kabul etmesi ve hayatını zenginleştirecek davranışları sürdürmede kararlı olması konusunda cesaretlendirerek onun anlamlı ve dolu bir yaşam sürdürmesine yardımcı olmaya çalışmaktadır.

Bu açıdan bakıldığında Kabul ve Adanmışlık Terapisi, bireylere olumsuz duygu ve düşüncelerin zihinlerini meşgul etmesini ve hatta bedenlerini etkilemesini anormal olarak görmemeyi; bu duygu ve düşüncelerle savaşmak yerine bu deneyimlerini olduğu gibi kabul ederek, tabiri caizse onları "bir misafir" gibi algılayarak, onlarla farklı, yeni yollarla ilişki kurmayı öğretmeyi ve şimdiki ana odaklı yaşamalarına yardımcı olmayı hedeflemektedir (Eifert ve Forsyth, 2005). Birey bütün bunları gerçekleştirebildiğinde ise psikolojik esnekliğe ulaşabilecektir (Hayes, Strosahl ve Wilson, 1999).

Bu çalışmanın amacı Kabul ve Adanmışlık Terapisi'ni ana hatları ile ele almak ve incelemektir. Bu bağlamda, öncelikle Davranışçı Terapilerin üç kuşağı incelenecek ve Kabul ve Adanmışlık Terapisinin ortaya çıkış süreci ele alınacaktır. Ardından ACT'ın kurucusu olan Steven C. Hayes'in hayatına yer verilecek, bu kısımdan sonra ACT'ın felsefi temelini oluşturan İşlevsel Bağlamsalcılık ve kuramsal zeminini oluşturan İlişkisel Çerçeve Kuramı üzerinde durulacaktır. Ardından kuramın insan doğasına bakışı, temel kavramları ve terapi süreci incelenecek sonrasında ise $\mathrm{ACT}^{\prime}$ 'ı etkililiğine dair yapılan çalışmaların sonuçları incelenecek ve son olarak ACT'a yapılan eleştirilere yer verilerek çalışma sonlandırılacaktır.

\section{Tarihsel Süreç: Davranışçı Terapilerin Üç Kuşağı ve ACT}

Watson (1925) ile temellerinin atılmasının üzerinden neredeyse bir asır geçen Davranışçı Terapi yaklaşımlarının tarihçesi içerisinde üç kuşağın (dalganın) yer aldığı ifade edilmektedir (Hayes, 2004). 
Birinci dalga Davranışçı Terapiler, dönemin hâkim psikoterapi akımı olan ve iç-görü, bilinçaltı vb. kavramlarla öne çıkan psikanalitik kurama tepki olarak ortaya çıkan davranışçı yaklaşımdır. Birinci dalga davranış terapilerindeki uygulamalara bakıldığında gözlemlenebilen davranışlar üzerine odaklanılmış ve bu davranışlar üzerinde klasik koşullama ve edimsel öğrenme gibi yöntemler kullanılarak değişiklikler gerçekleştirilmesi hedeflenmiştir (Vatan, 2016).

1960'ların sonlarına doğru gelindiğinde yeni davranışçı kuramcılar yalnızca gözlenebilen davranışlara odaklanmanın yeterli olmadığını, uyarıcı ile tepki arasındaki ilişkide bilişlerin de önemli olduğunu belirtmişlerdir. Birinci dalganın sonlarına doğru ikinci dalganın mimarları olan araştırmacılar işlevselliği bozan davranışların ortaya çıkmasında ve sürdürülmesinde işlevsel olmayan olumsuz düşüncelerin etkili olduklarını ifade etmişlerdir (Hayes, 2004). Böylece ikinci dalga Davranışçı Terapiler ortaya çıkmıştır. Albert Ellis'in (1962) Akılcı Duygusal Davranışçı Terapisi ve Beck'in (1964) Bilişsel Terapisi en bilinen ikinci dalga davranışçı terapi akımlarındandır. Bu iki kuramın yanı sıra, Meichenbaum'un (1977) Bilişsel-Davranışsal Değişme Terapisi ve Lazarus'un (1997) Çok Boyutlu Terapisi de ikinci dalga yaklaşımlar arasinda yer almaktadır (Vatan, 2016).

İkinci dalga davranış̧̧ terapiler, (özellikle bilişsel davranışçı terapi) düşünce ve inançları daha çok kontrol etme üzerine yoğunlaştığ için duyguları göz ardı etmesi bakımından eleştirilmektedir (İzgiman, 2014). Bilişsel davranışçı yaklaşımda işlevsel olmayan düşünce ve davranışlar arasındaki doğrudan ve dolaylı tüm ilişkilerde aslında bireyin içsel yaşantılarının göz ardı edildiği düşünülmektedir (Vatan, 2016). Bütün bu eleştiriler doğrultusunda bireyin içsel yaşantılarına önem veren, içgörü, farkındalık ve kabul gibi kavramlara odaklanan üçüncü dalga yaklaşımlar ortaya çıkmaya başlamıştır. Burada dalga metaforunun kullanılması manidardır ve önemli tartışmalara yol açmıştır. Kimileri bu "dalga" metaforunu daha önceki jenerasyonda gerçekleştirilen çalışmaların (BDT) yıkanıp geçeceği şeklinde algıladı fakat niyet ve sonuç olarak bu şekilde olmadı. Kıyıya çarpan dalgalar özümseyicidir ve bir önceki dalgaları da içerisinde barındırır fakat çarptıktan sonra arkasında farklı bir kıyı bırakır. Bundan sonrası için asıl değerlendirilmesi gereken üçüncü dalga yaklaşımlardan geriye kalanlardır (Hayes ve Hofmann, 2017).

Üçüncü dalga yaklaşımlar arasında diyalektik davranış terapisi (Linehan, 1993), metakognitif terapi (Wells, 2000), farkındalık temelli bilişsel terapi 
(Segal, Williams ve Teasdale, 2002), kabul ve Adanmışlık terapisi (Hayes ve Strosahl, 2004) ve duygu düzenleme terapisi (Berking ve Whitley, 2014) gibi yaklaşımlar yer almaktadır.

Söz konusu bu üçüncü dalga yaklaşımların ana temasını içsel deneyimlere dair farkındalık ve bu farkındalık ile birlikte kabul süreci oluşturmaktadır. Üçüncü dalga yaklaşımlarda içsel yaşantıların getirdiği bilişleri değiştirmek yerine kabul etme vurgulanmaktadır. Bu yaklaşımlar, psikolojik bir problem yaşandığında davranışı hemen patolojik olarak etiketlemek yerine bireyin güçlenmesine ve davranış repertuarının zenginleştirilmesine odaklanmaktadır. Öte yandan üçüncü dalga yaklaşımlarda terapi sürecinde kullanılan tekniklerin (örneğin, mindfulness alıştırmaları) etkili olabilmesinin ön koşulu olarak danışmanın da bu teknikleri deneyimlemiş olması gerektiği, uygulamadığı bir şeyi öğretmesinin de zor olacağı ifade edilmektedir. Böylelikle üçüncü dalga yaklaşımlarında danışman-danışan ilişkisinde herhangi bir hiyerarşik yapının söz konusu olmadığı söylenebilmektedir (Hayes, 2004).

Üçüncü dalga davranış terapileri arasında hem yaygınlık hem de bilimsel veriler bakımından en önde gelen yaklaşımın ise Kabul ve Adanmışlık Terapisi (Acceptance and Commitment Therapy-ACT) olduğu ifade edilmektedir (Hayes, 2004). Kabul ve Adanmışlık Terapisi, radikal davranışçı ekolden gelen, bilimsel verilerle etkililiği kanıtlanmış, felsefesini dil ve biliş arasındaki ilişki üzerine temellendiren (İlişkisel Çerçeve Kuramı-RFT) şimdiki ana odaklı, farkındalık temelli bir yaklaşımdır (Hayes, Strosahl ve Wilson, 1999). Kabul ve Adanmışlık Terapisinin temel amacı, bireyin, zorlayıcı düşünceler veya duygular ile arasındaki ilişkinin dönüştürülerek yeni bir yapı kazanmasıdır. Burada ACT, Bilişsel Davranışçı Terapiden farklı olarak bireyi zorlayan, hayatını olumsuz yönde etkileyen düşünceyi değiştirmek yerine o düşünceyle kurduğu ilişkiyi değiştirmeyi hedefler. Oluşturulan yeni yapıda, soruna yol açtı̆̆ düşünülen düşünce veya duygulardan uzaklaşmak yerine onlara daha yakından bakmak ve anlamaya çalışmak asıl amaçtır. Sonuç olarak belirtilerin azalması ACT'ın ana amacı olmaktan ziyade düşünce ve duygulara odaklanmanin ikincil getirisidir (Harris, 2006).

BDT ile ACT arasındaki farkı ortaya koyarken değinilmesi gereken önemli bir nokta da BDT'nin kanıta dayalı ve semptom odaklı bir terapiyken ACT'ın daha çok süreç temelli bir terapi oluşudur. Özellikle üçüncü dalga yaklaşımlarla birlikte terapide sürece ve bağlama yapılan vurgu artmıştır. Davranışçı terapi hareketinin ilk yıllarında Paul (1969; Akt. Hofmann ve Hayes, 2018) 
kanita dayalı tedavilerin asıl hedefi hakkında o meşhur klinik sorusunu sormuştur: "Bu özel sorunla bu birey için kim tarafından en etkili tedavi hangi koşullar altında ve nasıl ortaya çıkıyor?" Bu soru aslında bağlamsal olarak spesifik kanıta dayalı uygulamaları, sorunları çözen ve insanların refahını yükselten kanıta dayalı süreçlere bağlayan bir terapötik müdahale olan Süreç Temelli BDT'nin kapısını aralamıştır. Kanıta dayalı terapiler semptomlar üzerinde dururlar ve semptomlar üzerinden protokoller oluştururlar. Kanita dayalı terapiler, semptomların altından neler yattığını, etiyolojisi ve bozukluğun mekanizmasını anlamaya çalışır. Böylece değişimin nasıl olacağını anlamaya çalışmaktadır. Süreç temelli terapiler ise, hastalığa özgü belirtilere farklı yollarla neden olan işlevsel süreç üzerinde dururlar. İşlevsel bir sürecin birçok farklı bulguya yol açabileceğini ve klinik bir belirtinin birçok farklı işlevsel süreçten kaynaklanabileceğini vurgulamaktadır. Bu nedenle de en etkili ve işlevsel değişimin nasıl olacağına odaklanırlar. Süreç temelli terapinin temel sorusu şudur: "Bu durumda bu amaçlar göz önüne alındığında bu danışanla hangi temel biyopsikososyal süreçler hedeflenmelidir ve en etkili ve etkin biçimde nasıl değiştirilebilir?" Hayes, bu noktada psikolojik esneklik modelinin bunu sağlayabileceğine vurgu yapmaktadır. Buna bir örnek vermek gerekirse süreç temelli bir terapide, travma mağdurlarında görülen depresyon için en iyi tedavi yöntemini bulmak yerine uğradığı fiziksel saldırıdan sonra ruminatif dikkat katılığı ve duygusal kaçınma kalıpları geliştiren bir danışanda sosyal geri çekilmeyi azaltmaya, daha anlamlı ve samimi ilişkiler geliştirmeye odaklanılabilir (Hayes ve ark., 2019).

Tamamen sendroma odaklanma zayıfladıkça ve sürece odaklanma güçlendikçe; sadece psikopatoloji değil, insanın psikolojik refahı ve bütün insanların gelişmesi de daha merkezi hale gelmektedir. Sonuç olarak insanların davranışsal ve zihinsel sağlığı yalnızca psikolojik bozuklukların olmamasından ibaret değildir. Bütün bu değişiklikler, kanıta dayalı tedavide, tüm psikososyal ve bağlamsal biyolojik süreçleri bütünleştirmeyi amaçlayan, süreç temelli bir alana geçişi hızlandırmaktadır. Bireylerin davranışsal ve zihinsel sağlıklarında bir fark yaratabilen değişebilir süreçlere odaklanmak, kanıta dayalı terapilerin ve birey merkezli terapilerin süreç temelli terapinin tek bir çatısı altında birleşmesi için bir yol sağlamaktadır. Alanın bu yönde yönlendirilmesi, sonuçta BDT'nin üçüncü dalgası tarafından üretilen en önemli “değiştirilmiş kıyı" olabilir (Hayes ve Hofmann, 2017). 
BDT yaklaşımıyla ACT arasındaki fark her ne kadar müdahale alanları hususunda görünse de daha çok felsefi ve bilimsel yöntem bakımından bu iki kuram farklılaşmaktadır. Bu durumu bir örnekle açılamak gerekirse, BDT yaklaşımında her psikolojik probleme özgü işlevsel olmayan anahtar kognisyonlar (bilişler) olduğu düşünülür ve tedavi bu kognisyonların işlevsel olanlarla çeşitli teknikler (bilişsel yeniden yapılandırma, alıştırma tedavileri, yönlendirilmiş keşif vb.) vasıtasıyla değiştirilmesine odaklanmaktadır (Beck, 1970). ACT'ın ise bilişsel modelden farklı olarak duygu, düşünce, imaj, dürtü vb. herhangi bir içsel yaşantıyı değiştirme, sıklık ya da yoğunluğunu azaltma gibi bir amacı bulunmamaktadır. Bu yönüyle ACT, geleneksel BDT yaklaşımlarından müdahale bakımından farklılaşmaktadır (Yavuz, 2015).

Kabul ve Adanmışlık Terapisi'nin İngilizce'deki karşılığı olan “Acceptance and Commitment Therapy" nin baş harfleri birleştirilerek ACT kısaltması elde edilir. "ACT" kelimesi İngilizcede harekete geçmek anlamı taşır ve kuramı benimseyen kişiler kuramın temel ilkelerinden biri olan eyleme geçmeyi vurguladığ 1 için harfleri teker teker okumak yerine kelime olarak söylemeyi tercih etmektedirler. Kabul ve Adanmışlık Terapisi temel olarak üç süreçten oluşmaktadır (Harris, 2016; Terzi ve Tekinalp, 2013):

$\mathrm{A}=$ Düşünce ve duyguların kabul et, anda ol (Acceptance of your thoughts and feelings and be present)

$\mathrm{C}=$ Değer odaklı bir eylem seç (Choose a valued direction)

$\mathrm{T}=$ Harekete geç (Take action)

\section{Steven C. Hayes}

Steven C. Hayes Nevada Üniversitesi Psikoloji Bölümünde Davranış Analizi programında profesördür. 44 kitap ve 600'e yakın makalesi bulunan Hayes'in çalışmaları insan dilinin ve bilişinin doğasını anlamaya ve bu yolla insan ıstırabının anlaşılması ve hafifletilmesine odaklanmıştır. Hayes, İlişkisel Çerçeve Teorisi'nin geliştiricisi ve aynı zamanda farkındalık, kabullenme ve değerlere dayalı yöntemleri kullanan, kanıta dayalı popüler bir psikoterapi biçimi olan Kabul ve Adanmışlık Terapisi'nin (ACT) de kurucularındandır. Dr. Hayes, Amerikan Uygulamalı ve Önleyici Psikoloji Derneği, Bağlamsal Davranış Bilimleri Derneği ile Davranış̧̧ı ve Bilişsel Terapi Derneği başkanlığını da yürütmüştür. Birçok kuramın ortaya çıkış hikâyesinde kuramı geliştiren kişi ya bir arayış içindedir ya da bir bakıma çaresiz kalmıştır. Kabul ve Adanmışlık 
Terapisinin de ortaya çıkışı hemen hemen bu şekilde olmuştur. Kuramın kurucularından olan Steven Hayes'i belki de kuramını geliştirme yolunda en çok etkileyen durumlardan birisi de kendisinin aslında panik bozukluktan muzdarip olması ve yıllarca bu soruna bir çözüm arayıp bulamamasıdır.

Kabul ve Adanmışlık Terapisinin felsefi temelini İşlevsel Bağlamsalcılık (Functional Contextualism), kuramsal temelini ise İlişkisel Çerçeve Kuramı (Relational Frame Theory) oluşturmaktadır. Bir sonraki bölümde bu iki kuram detaylı bir şekilde incelenecektir.

\section{Kabul ve Adanmışlık Terapisinin Felsefi Temeli: İşlevsel Bağlamsalcılık}

ACT'ın temel felsefesini dayandırdığı İşlevsel Bağlamsalcılık yaklaşımına göre psikolojik olaylar, birey ile hem tarihsel (öğrenme geçmişi) hem de durumsal (öncüller, sonuçlar) bağlam arasındaki etkileşimler olarak ifade edilmektedir. Dolayısıyla bir olayın analiz edilebilmesi ancak o olayın tarihsel arka planının ve gerçekleşme amacının incelenmesiyle mümkün olabilmektedir. Bir davranışın öngörülebilmesi ve yönlendirilebilmesi ise ancak bağlamsal değişkenlerin netleştirilmesi ile mümkün olabilmektedir (Hayes, 2015). İşlevsel bağlamsalcılık perspektifine göre danışanın davranışlarının faydalı ve işlevsel olarak kabul edilebilmesi eylemleri ile değerlerinin uyumlu içeriklerde olmasına bağlıdır (Hayes vd, 2004).

İşlevsel bağlamsalcılığı mekanistik yaklaşımlardan özellikle ayıran şey ise çevre-davranış ilişkisini ele alış biçimidir. Bu yaklaşıma göre, çevre ve davranış birbirinden bağımsız değil birbirini tamamlayan değişkenler olarak ele alınmaktadır. Bu sebeple işlevsel bağlamsalcllıkta nasıl canlı bir varlık olmaksızın çevreyi incelemek anlamsızsa bağlamdan ayrı davranışı incelemek de o denli anlamsız görülmektedir (Hayes, Barnes-Holmes ve Wilson, 2012).

Düşünce ve davranış arasındaki ilişki gibi iki psikolojik olayın etkileşimi üzerine kurulan modeller (örneğin; bilişsel model) bağlamsal değişkenleri tam olarak ortaya koyma konusunda güçlük çekmektedirler. Her ne kadar düşünce belirli bir davranışla ilişkili olsa da bu düşünce ve davranışsal olayın birlikte ortaya çıkmasına zemin hazırlayan belirli bir tarihsel ve durumsal bağlamdır (Yavuz, 2015).

Kabul ve Adanmışlık Terapisi ise psikolojik olayları, canlılar ile tarihsel ve durumsal olarak tanımlanmış bağlamlar arasında meydana gelen ve sürekli olan etkileşimler olarak tanımlamaktadır. ACT'a göre danışanın problematik 
davranışını olayın bulunduğu bağlamdan ayırmanın, problemin doğasını anlayabilme ve ona çözüm bulma olanağını kaçırmaya sebep olacağı düşünülmektedir (Hayes, Barnes-Holmes ve Wilson, 2012).

\section{Kabul ve Adanmışlık Terapisinin Kuramsal Temeli: İlişkisel Çerçeve Kuramı}

$\mathrm{ACT}^{\prime}$ ın kuramsal zeminini işlevsel bağlamsalc felsefe temelinde, insan dili ve bilişinin doğası üzerine geliştirilmiş ve bir davranış analizi dalı olan İlişkisel Çerçeve Kuramı (Relational Frame Theory) oluşturmaktadır. Hem insan hem de diğer hayvan türleri, olaylar ve şeyleri renk, şekil gibi fiziksel özellikleri üzerinden karşılıklı ve kombinasyonel bir biçimde ilişkilendirebilme yeteneğine sahiptir. Fakat insan, diğer türlerden farklı olarak fiziksel özelliklerin yanı sıra soyut çıkarımsal (iyi, kötü, kıymetli vb.) özellikler aracılığıyla da karşılıklı ve kombinasyonel ilişkilendirme davranışı sergileyebilme yeteneğine sahiptir (Hayes, 2004).

İnsanlar dil becerisini edinmeye bebeklikten itibaren başlamakta ve kelimeler ile nesneler arasında bağlantılar kurmaktadır. Bu bağlantı nesneleri isimlendirme ile başlar ve doğası gereği nesneler ile kelimeler arasındaki bu öğrenilmiş ilişki çift yönlüdür. Yani öğrenilen kelime duyulduğunda veya düşünüldügüunde zihinde o nesne canlanmakta, nesne görüldügünde ise akla o kelime gelmektedir. Örneğin bir çocuk kedi kelimesini öğrendiği zaman artık kedi kelimesini işittiğinde kedi resmi zihninde canlanabilecek ve kedi gördügünde kelime olarak da söyleyebilecektir. Çocuk büyüdükçe ve bilişsel gelişimi arttıkça sözel imgelemler daha karmaşık bir hal alacaktır. Dolayısıyla kişinin kurduğu bu ilişkiyi zihninden silmesi mümkün değildir. Buna bir başka örnek ise bir çocuğun annesini ilk etapta adı ve soyadı ile tanımaması fakat zaman geçtikçe çevresindekiler annesine ismiyle ve soy ismiyle seslendikçe artık çocuk için bu diğer kelimelerin de annesini temsil ediyor olmasıdir (Pearson, Heffner ve Follette, 2010).

İlişkisel öğrenmenin üç temel özelliği olduğu ifade edilmektedir. Bunların ilki olayların çift yönlülük göstermesidir. Örneğin A'nın, B ile aynı olduğunu öğrenirsek; B'nin de A ile aynı olduğu sonucuna varırız. Başka bir örnekte, "Ali, Ahmet'ten büyüktür" bilgisi kişiye verildiğinde Ahmet'in Ali'den küçük olduğu bilgisi de o kişi tarafından türetilir. İkinci özellik ise farklı ilişkilerin birleştirilebilmesidir. Örneğin $X, Y$ ile; $Y$ de Z ile aynı ise; Z'nin $X, X^{\prime}$ in de 
Z ile aynı olduğu sonucuna varılır. Bir çocuk tamın yarımdan büyük olduğunu ve çeyreğin de yarımdan küçük olduğunu öğrenirse, tamın çeyrekten büyük olduğu sonucuna varacaktır. Üçüncü ve son olarak, bazı ilişkiler uyaran işlevlerinin ilgili diğer uyaranlar arasında da dönüştürülmesine olanak sağlamaktadır. Örneğin bir çocuk markete şeker almaya gittiğinde şekerin fiyatına göre elindeki paralardan seçerek ücreti ödeyecektir. Bu üç özellik bağlamında ele alınan ilişkisel tepkiler, ilişkisel çerçevelendirme olarak tanımlanmaktadır (Hayes, Barnes-Holmes ve Roche, 2001; Hayes, 2004).

İlişkisel çerçeveyi insan davranışlarının ele alınması ve anlamlandırılması hususunda anlamlı kılan şey ise mevcut bir durum ya da olayın bir öğesine atfedilmiş bir işlevin diğer öğelerin işlevlerini de etkileme eğilimi göstermesidir. Örneğin bir ay öncesinde Reyyan köpeğini gezdirirken köpeği birden yola firlamış ve huzla gelen bir araba korna çalarak son anda frenlemiş ve durmuştur. Köpeğine az kalsın araba çarpacak olan Reyyan ve köpeği bu durumdan son derece etkilenmiş ve çok korkmuştur. Reyyan'ın köpeği için o arabaya fiziksel olarak benzeyen şeyler ya da benzer sesler aynı korkuyu tetikleyebilecekken, Reyyan tamamen güvenli evinde otururken veya okulda ders dinlerken bile aynı korkuyu yeniden deneyimleyebilir. Reyyan'ın duyduğu ya da gördüğü herhangi bir şey, o andan başka birine bahsetmesi veya o anı düşünmesi; aynı duygu ve fiziksel duyumları yaşamasına yol açabilmektedir. Bu örnekten hareketle şu sonuca varılabilir: "dil aracilı̆̆ıyla her şey acı kaynağı haline gelebilir" ve dahası yaşanılan acının şiddeti yine dil aracılığıyla arttırılabilir (Törneke, 2010).

Dil aracilığıyla deneyimlenen içsel yaşantılara hoşa giden veya gitmeyen işlevler eklenebilir, bu yaşantılarla ilgili birtakım kurallar geliştirilebilir: "Kaygı kötüdür.", "Kaygı kurtulunması gereken bir duygudur." vb. Bu bağlamda bakıldığında bireyler hoşlarına giden duyguların peşinden koşarken, gitmeyenlerden kurtulmaya çalışır. Her ne kadar dış dünyadaki istenmeyen şeylerden kaçıp kurtulmak mümkün olsa da bu strateji iç dünya için işe yaramayabilir. Çünkü dil aracılığıyla kurulan ilişkiler öğrenilir ve öğrenilen bir şeyin öğrenilmemiş hale gelmesi mümkün değildir. Aksine bu içsel sembolik tehditlerden kaçınma çabası paradoksal etkilere yol açabilmekte, acıdan kaçmak için kullanılan yöntem bir süre sonra acının kaynağı haline gelebilmektedir (Terzioğlu ve Yavuz, t.y.) 


\section{Kabul ve Adanmışlık Terapisinin İnsan Doğasına Bakışı}

İnsanlar yaşam içerisinde kaçınılmaz bir şekilde pek çok acı, kayıp, başarısızlık, ve hayal kırıklıkları ile karşılaşmaktadır. Doğası gereği öfke, pişmanlık, nefret, suçluluk gibi pek çok acı veren duyguyu tekrar tekrar deneyimleyebilmektedir. Bunun yanı sıra insan zihni tüm bu acı verici olay ve durumları herhangi bir zaman diliminde hatırlayarak etkilenebilmekte ve geleceğe karamsar bakabilmektedir. Kabul ve Adanmışlık Terapisi, insanın böylesine büyük bir acı içindeyken dahi bir anlam, amaç ve dayanma gücü bulma firsatının olabileceğini öne sürmektedir (Harris, 2016). İnsanlar herhangi bir sorunla karşı karşıya kaldıklarında onu çözmeye, üstesinden gelmeye ve sorundan kurtulmaya meyillidirler. Arabası bozulduğunda, hastalandığında veya sınavdan kötü bir not aldığında insanlar bu sorunlar karşısında çeşitli yöntemler deneyerek sorunu çözüme kavuşturabilmektedir. Ancak "düzeltonar-kurtul" mantığını içsel deneyimlerinde de kullanmaya çalıştıklarında bireyin iç dünyasında yaşadıkları ile dış dünyadakiler benzerlik göstermediğinden söz konusu strateji pek işe yaramamaktadır. İnsan, ileriye doğru yürüdüğü yolda beraberinde geçmişini, yaşadığı psikolojik acıları ve içsel tecrübelerini de götürmektedir. ACT'a göre bu içsel deneyimler bireyin kişisel tarihinin bir parçasıdır, bundan dolayı kurtulunması gereken şeyler değildir (Hayes ve Smith, 2005).

Klasik batı psikolojisini benimseyen ve bireyin psikolojik belirtilerinin azaltılmasına odaklanan pek çok terapi yaklaşımının aksine ACT, şimdiki ana dayalı ve değerler doğrultusunda bir yaşam sürdürmesi konusunda bireyi desteklemektedir. İnsanın ana odaklı ve değerleri doğrultusunda eylemde bulunma durumu, psikolojik belirtilerinden bağımsız bir şekilde gerçekleşebilmektedir. Bu sebeple, bireyin potansiyeline güvenen bir perspektife sahip olan ACT, bireyin söz konusu belirtilerini azaltmak yerine bu belirtilerle kurduğu ilişkiyi değiştirmeye odaklanarak sonuca ulaşmak üzerine kurgulanmıştır. Terapi sürecinde danışanın bu belirtilerle kurduğu ilişki değiştiğinde dolaylı olarak belirtilerinde bir azalma meydana geleceği düşünülmektedir (Harris, 2016). 


\section{Kabul ve Adanmışlık Terapisindeki Temel Kavramlar}

\section{Psikolojik Esneklik}

Psikolojik esneklik, bireyin içsel yaşantılarına dikkat ve açıklıkla yaklaşarak ânla temas halinde ve değerleri doğrultusunda davranışlar sergilemekte kararlı olması durumu olarak tanımlanmaktadır. Bir diğer ifadeyle, anlamlı ve dolu dolu bir hayat için bireyin önünde engel gibi duran duygu, düşünce ve anıların fark ederek; onları değiştirmeye, kontrol etmeye veya yoğunluklarını ya da sıklıklarını azaltmaya çalışmaksızın davranışları üzerindeki baskınlıklarını zayıflatmak ve böylece değer verdiği alanlardaki davranışlarında Adanmışlık göstermesi temel amaçtır. Danışma sürecinde de asıl amaç, danışanın psikolojik esneklik düzeyinin arttırılmasıdır. Psikolojik esneklik düzeyi yüksek birey, yaşamında karşılaştığı zorluk, kriz ve travmatik yaşantılara karşı daha işlevsel baş etme davranışları sergileyebilmektedir (Strosahl, 2004; Harris, 2016). Psikolojik esneklik modeli bir diğer adıyla "esnek altıgen modeli" altı temel terapötik süreçten meydana gelmektedir: an ile esnek temas, kabul, bilişsel ayrışma, bağlamsal benlik, değerlerle temas ve değer odaklı davranışlarda adanmışlık. Bir sonraki bölümde bu altı süreç ana hatlarıyla ele alınacaktır.

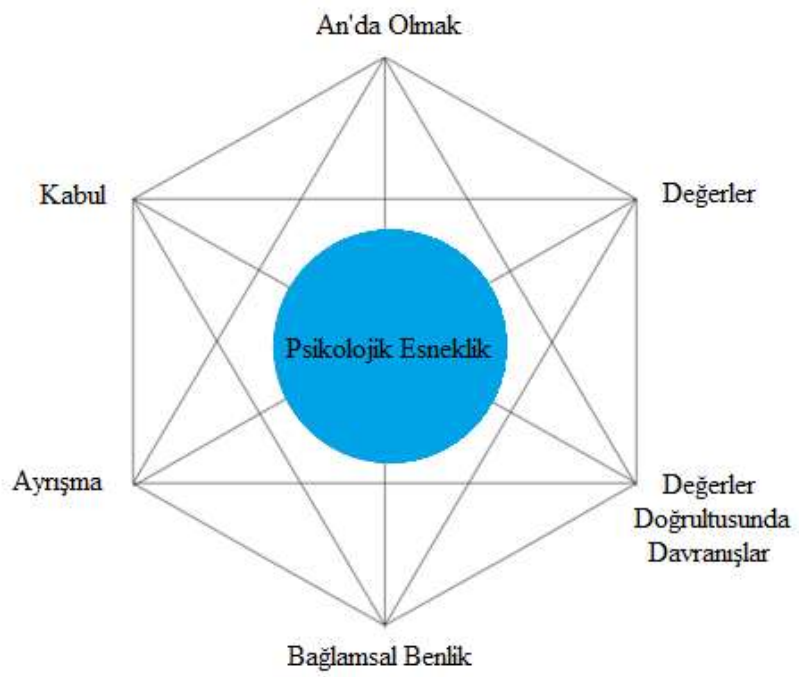

Şekil 1. Kabul ve Adanmışlık Terapisinin Psikolojik Esneklik Modeli (Harris, 2016) 


\section{An'da Olmak}

İnsanlar genellikle zamanlarının büyük bir kısmını geçmişi düşünerek, geçmişte yaşadıkları olayları ve olayların nasıl daha farklı olabileceğine ilişkin değerlendirmeler yaparak geçirmektedir. İnsan zihni bu anıların üzerinden tekrar tekrar geçerek nelerin yaşandığı ve aslında ne olması gerektiği üzerinde çeşitli kurgular ve hikâyeler oluşturarak tekrar benzer sorunların, benzer acıların yaşanmaması için nelerden kaçınmak gerektiğini planlamaktadır. Bu senaryolar zaman geçtikçe artmakta, yaygınlaşmakta ve bireyin yaşamındaki işlevselliğini de kısıtlayabilmektedir (Bolderston, 2013). Öte yandan insan zihni geleceğe odaklandığında bu kez de kaygilarla birlikte felaket senaryoları oluşturabilmekte ve bireyi umutsuzluğa sürükleyebilmektedir. Sonuç olarak gelecek bilinemez ve kontrol edilemez olduğundan insanlar yaşadıkları kötü deneyimlerin gelecekte de süreceğini düşünerek endişeye kapılmakta ve içinde bulunduğu anı ve yaşadıklarını kaçırmaktadır. Şimdiki zamanla temas halinde olma, düşünceler arasında kaybolmadan şu anda tecrübe edilen şeyin farkında ve bilincinde olarak şimdi ve burada olmak demektir. Kabul ve Adanmışlık Terapisi için danışanın içinde bulunulan ana ilişkin farkındalığının sağlanması çok önemlidir. Zira danışanın geçmişle ilgili yorumları ve geleceğe dair varsayımlarından ziyade an içerisinde deneyimlediği şeylere odaklanmanın ACT'ın diğer beş temel sürecinin de daha iyi işlemesine fayda sağlayacağı düşünülmektedir (Hayes vd. 2004).

\section{Kabul}

Kabul, ACT'in en temel süreçlerinden biridir. Kabul, kişinin kendisine acı veren duygulara, yaşantılara, anılara ve dürtülere zihninde bir alan oluşturması ve oluşturduğu alanda bütün bunlara bir hareket alanı sağlayarak onlarla mücadele etmeden orada bulunmaların sağlamaktır. Buradan bu olumsuz, acı veren yaşantıları sevmek ya da onları istemek anlamı çıkarılmamalıdır. $\mathrm{Bu}$ nedenle kabullenmenin, değerlerle uyumlu bir biçimde eylemde bulunma adına kaçınılan uyaranlara yaklaşma davranışı olarak ifade edilmesinin daha isabetli olacağı düşünülmektedir (Blackledge ve Barnes-Holmes, 2009). Bütün bu istenmeyen duygu, düşünce, duyum ve anıları adeta birer misafir gibi görmek ve gelip gitmelerine izin vermek kabul sürecinde dikkat edilmesi gereken noktadır. Bu içsel yaşantılardan kaçınmaya çalışmak bireyi 
daha çok sorunun içine sokarak bir çıkmaza sürüklemekte; bu düşünce ve duyguların zihinde belirip kaybolmalarına izin vermek bireye istediği hayatı yaşayabilme, seçimler yaparak harekete geçebilme özgürlüğünü sağlamaktadır (Walser ve Westrup, 2007).

\section{Ayrışma}

Bir kişi evinde oturmuş bir kitap okurken kitabın ana karakterinin yaşamış olduğu üzüntü verici bir olay ona kendi yaşantılarını hatırlatabilmekte ve geçmişte yaşamış olduğu olumsuz duygu ve düşünceleri tekrar yaşamasına sebep olabilmektedir. Böyle bir durumun insan zihninin kompleks yapısı ve özellikle dil yetisi ile bağlantılı olduğu düşünülmektedir. Herhangi bir fiziki acı olmasa da o acıya dair herhangi bir düşünce bireyin canını yakabilmektedir. Birisi için sıradan denebilecek bir kelime başka bir kişi için o kişinin zihninde yaşantıları ile ilişkilendirildiğinden kaygı, korku, üzüntü, hayal kırıklığ $1 \mathrm{vb}$. duyguları hissetmesine neden olabilmektedir.

Ayrışma, bireylerin duygu, düşünce ve hatıraları, kendileri ve çevrelerine ilişkin gerçekler olarak görmeyip, onları yalnızca içsel yaşantılar gibi bir fenomen olarak tanımlayabilme yetisini ifade etmektedir. Bir başka ifadeyle düşünce ile o düşünceyi düşünen kişi arasına mesafe konulmasıdır (Walser ve Westrup, 2007). ACT tedavi süresince sıkça metaforlardan faydalanmaktadır. Bilişsel ayrışmayı daha iyi anlayabilmek adına "Eller Metaforu" (Harris, 2016) kullanilan metaforlardan birisidir. Eller metaforunda, bireye ellerinin olumsuz duygu ve düşüncelerini temsil ettiği söylenir ve ardından ellerini avuç içleri yukarı bakacak şekilde tutarak yavaşça yüzüne yaklaştırması istenir. Ellerini tam olarak yüzünün karşısına getirdiğinde danışandan etrafa bakması ve ne gördüğüne dikkat etmesi söylenir. Yüzünün hemen önünde duran ellerinden (yani olumsuz düşünce ve duyguları) ötürü danışan herhangi bir şey göremez ve danışman ona neyi ne kadar görebildiğini, neyi ne kadar kaçırdığını ve bu şekilde güne başlayıp yataktan kalktığını, araba kullandığını, partiye gittiğini düşünmesini ister. Daha sonra yavaşça ellerini yüzünden aşağıya doğru indirmesini ister, elleri yüzünden uzaklaştıkça yani düşünceleri ile arasına mesafe koydukça ne deneyimlediğini sorar ve ellerinin (yani düşüncelerinin) hala orada olduğunu vurgular. Böylece bilişsel ayrışmanın aslında olumsuz düşünceleri ve duyguları yok saymadan, onlardan 
kurtulmaya çalışmadan yalnızca bu düşünceler ile danışanın kendisi arasına mesafe koymasını sağlamak olduğunu ifade etmektedir.

Bilişsel birleşme kavramı ise, düşüncelerin yalnızca düşünce olmaktan ç1kıp gerçekten kişiyi tanımlayan ifadeler olarak kabul edilmesi durumunu ifade etmektedir. Örneğin "beceriksizin tekiyim" düşüncesi ile birleşen bir danışan için artık bu sadece bir düşünce değil, onun gerçeği olmuştur. Bundan dolayı da herhangi bir işe başlayacağı esnada "beceriksizin tekiyim" perspektifinden bakarak belki de aslında becerebileceği, üstesinden gelebileceği bir işe bile başlamak istemeyerek kaçınabilmektedir (Bolderston, 2013).

\section{Bağlamsal Benlik}

İnsan, yaşantılarını duyu organları vasıtasıyla algıladığı fiziksel bir benliğe; düşünme, hatırlama, yargılama gibi zihinsel yetiler aracılığıyla algıladığı düşünsel bir benliğe ve bu iki benliği izleyen bir gözlemleyen (bağlamsal) benliğe sahiptir (Harris, 2016). Bağlamsal benlik kişinin yargısız bir biçimde kabul deneyimi yaşaması, şimdi ve buradayı olduğu gibi tecrübe edebilmesidir. Bağlamsal benliğin gözlem halinde olması "saf farkındalık" olarak nitelendirilmektedir (Harris, 2016). Söz konusu gözlem hem içsel-psikolojik duyumları hem de dış dünyada meydana gelen olayları bütüncül bir perspektifle aynı anda fark edebilmeyi ifade etmektedir. Kişilerin duyguları, düşünceleri, değerleri ve algıları zamanla değişime uğrasa da bağlamsal benlik içerisinde yer alan gözlemleyen "ben” değişmemektedir (Harris, 2016). Bağlamsal benlik, kişinin anlık yaşantılarının ötesine geçerek benliğini algılamasıdır. Başka bir ifadeyle kişinin kendisi ile dış dünya arasına bir sınır çizerek buradan kendisini gözlemesidir (Terzi ve Tekinalp, 2013). Bağlamsal benlik bir tren istasyonuna benzetilebilir. İstasyon, her zaman aynı yerde sabit durur ve gelen giden trenlere tanık olur. Aynı burada olduğu gibi, insan da başından türlü türlü olaylar geçse de, tren istasyonu gibi aslında benliği/kendisi olduğu yerde sabit bir biçimde durmakta ve kendisini yaşadığı olaylarla bir bütün olarak değerlendirmemelidir.

\section{Değerler}

Değerler, kişinin hayatta ne yapmak, neyi temsil etmek ve nasıl biri olmak istediğini ve bu doğrultuda nasıl davranmak istediğini ifade etmektedir (Ha- 
yes, Strosahl ve Wilson, 1999). Birey hayatının sonunda nasıl biri olarak hatırlanmak istiyorsa, değerleri de bu doğrultuda olacak (Ögel, 2015). Değerler, hayatı boyunca bireye harekete geçme konusunda motivasyon kaynağı olan ve ona rehberlik eden ilkelerdir. Kabul ve Adanmışlık Terapisinde danışana sık sık "Nasıl bir hayat istersin?" "Bu hayatta senin için önemli ve anlamlı olan şeyler nelerdir?" gibi sorular sorularak bireyin değerlerini keşfedebilmesine yardımcı olunmaktadır (Bach ve Moran, 2008). Değerler ve hedefler sıklıkla karıştırılmaktadır. Değerler ve hedefler özü itibariyle farklılık göstermektedirler. Değerler daha çok süreç temellidir ve genellikle bir sonu yoktur. Öte yandan hedefler gerçekleştirilebilir ve gerçekleştirildiğinde hedef listesinde üstü çizilir. Bu minvalde bakıldığında değerler varılacak bir menzilden ziyade yolda olma anlamına gelmektedir (Walser ve Westrup, 2007). Örneğin kilo vermek bir hedeftir, gerçekleştirilir ve biter. Sağlıklı bir yaşam sürmek ise bir değerdir ve yaşam boyu sürebilir. Davranışlar değer odaklı olduğunda verimi artmakta ve kişinin iyi oluşuna fayda sağlamaktadır (Hayes, Strosahl ve Wilson, 1999). Kişinin nereye gideceğini seçmesi nereye gitmeyeceğini seçmesine nazaran daha işlevseldir. Tıpkı pusulası yardımıyla rotasını belirlemiş bir kaptan gibi bireyin gideceği yönü belirlemiş olması, ne tür seçimler yapacağını ve ne şekilde ilerleyeceğini kolaylaştırmaktadır. Tam tersine bireyin nereye gitmeyeceği ile meşgul olması daima bir şeylerden kaçmaya çalışması ve kendisini sürekli sınırlandırması ile sonuçlanmaktadır (Bach ve Moran, 2008). Kabul ve Adanmışlık terapisi bireyin güçlü ve kendinden emin bir şekilde, aktif olarak değerlerinin peşinden gitmesi fakat değerlerini eyleme dökerken katı kurallar oluşturmaması gerektiğini vurgulamaktadır. Değerlerin eyleme geçirilmesi noktasında sergilenecek katı bir tutum, bireyin değerleriyle birleşme yaşamasına, bu değerlerin uyulması gereken emirler gibi algılanarak kişinin kendisini baskı altında ve sınırlandırılmış hissetmesine yol açabilmektedir (Harris, 2016).

\section{Değerler Doğrultusunda Davranışlar}

Değer odaklı eylemler, kişinin değerleri tarafından yönlendirilen etkili eylemlerdir. Terapi sürecinde danışanın bulduğu değerleri kıymetlidir fakat sadece bu değerlerin farkında olmak yaşamın daha anlamlı, zengin ve dolu kılmaya yeterli değildir. Bir kaptanın yalnızca elindeki pusulaya bakması onun tam anlamıla yolculuk yaptı̆̆ı anlamına gelmez. Kararlı eylem, zor 
durumlara kolayca uyum sağlayabilme, davranışı sürdürebilme ya da gerektiği zaman uygun değişiklikler yapabilme ve değerleri doğrultusunda davranma gibi esnek eylemleri içermektedir. Tedavi sürecinde değerlerin sürdürülebilir ve değer yönelimli davranışlara dönüştürülmesi hedeflenmektedir (Harris, 2016). ACT sürecinde öncelikle birey değerleri doğrultusunda hareket edeceğini sözel olarak ifade etmektedir. Daha sonra bu doğrultuda gerçekleştireceği davranışsal süreçler belirlenmekte ve açk bir şekilde ortaya konmaktadır. Böylece netlik kazandırılan davranışsal süreçlerin gerçekleştirilme olasılığı artmaktadır (Bolderston, 2013).

\section{Kabul ve Adanmışlık Terapisi'nde Danışma Süreci ve Kullanılan Teknikler}

ACT'nin terapideki amacı kişilerde psikolojik esneklik geliştirmek başka bir ifadeyle, kişilerin psikolojik katılık düzeylerini azaltmaya yardım etmektir. Psikolojik esneklik, bireylerin değerleri doğrultusunda eylemler gerçekleştirirken şimdiki anda ortaya çıkan yaşantıların farkında ve onları kabul etmeye açık olması durumu olarak ifade edilmektedir (Harris, 2016). Terapi sürecinin sonunda da danışanın şimdiki ana odaklı ve değerler doğrultusunda sürdürülmeye kararlı bir hayata sahip olması hedeflenmektedir. ACT, her seansta danışanın psikolojik esnekliğini arttırmayı hedeflemektedir. Danışanın an ile temas ederek, değer odaklı işlevsel eylemlerde bulunması onu canlılığa doğru yöneltmektedir. Kabul ve Adanmışlık Terapisindeki canlılık (zindelik), herhangi bir duygudan öte ve ziyade hayatı kimi zaman acı verici de olsa bütünüyle kucaklamak şeklinde ortaya çıkmaktadır. ACT'ta terapi sürecinde danışanın acı (ıstırap) çekme tarafından canlılık tarafına geçişine yardımcı olmak hedeflenmektedir (Harris, 2016).

ACT, danışma sürecinde birçok farklı teknikten faydalanmaktadır. Bunlardan biri de metaforlardır. Her ne kadar felsefi ve kuramsal bağlamı $\mathrm{ACT}^{\prime} 1$ anlaşılması güç bir yaklaşım olarak gösterse de bu karmaşık süreçleri anlatmak için danışman metaforlardan yararlanmaktadır. Bunlardan biri de "Parti Metaforu"dur (İzgiman, 2014). Danışman danışana parti metaforunu şu şekilde ifade edebilmektedir: "Büyük bir parti verdiğinizi düşünün. Bu parti herkese açık bir parti, herkes gelebilir. Arkadaşlarınızı arıyor çevrenize haber veriyorsunuz ve partiniz için büyük hazırlıklar yapıyorsunuz. Beklenen gün geliyor ve arkadaşlarınızın gelmesiyle eviniz yavaş yavaş dolmaya başlıyor. 
Her şey harika giderken birden kapı çalıyor ve siz bu kez gelenin kim olduğunu tahmin etmeye çalışarak kapıyı açıyorsunuz. Kapıyı açtığınızda gelenin kaba saba, bakımsız ve sevmediğiniz bir komşunuz olduğunu görüyorsunuz. Onu içeri almak istemiyorsunuz fakat o bir merhaba bile demeden içeri dalıyor ve partiye arkadaşlarınızın arasına katılıyor, kaba bir şekilde yiyip içip konuşuyor. Çok utanmış ve de kızgın hissediyorsunuz. Dayanamayıp bu kadarı yeter diyerek onu evden kovuyorsunuz. O gidince kendinizi rahat hissediyorsunuz ve partinize dönerek kaldığınız yerden devam ediyorsunuz. Aradan bir süre geçtikten sonra yeniden kapı çalıyor ve açtı̆ınızda yine o kaba komşunuz olduğunu görüyorsunuz daha siz dur diyemeden o direkt içeri dalıyor ve partiye katıllyor. Onu tekrar kovuyorsunuz. Bu sefer işi garantiye almak için kapının önünde bekliyorsunuz ve bu sorunu çözüyor. Komşunuz artık partide değil. Ama asıl sorun şu ki siz de kendi partinizi kaçırıyorsunuz. Komşunuzun partiye tekrar gelmesini riske atmak istemiyor ve ne yapacağınızı bilemiyorsunuz. Partiye dönüp eğlenmek istiyorsunuz ama komşunuzun orada olacağı düşüncesi sizi oldukça rahatsız ediyor. Bir süre sonra bu partinin sizin için önemli olduğunu düşünerek içeri geçiyor ve kaldığınız yerden devam ediyorsunuz. Düşündügüunüz şey gerçekleşiyor ve komşunuz geri geliyor ve yine rahatsız edici oluyor. Fakat bu sefer durum farkl. Öncelikle komşunuz orada duruyor ve onu görmezden gelmeniz mümkün değil. Ama yine de siz arkadaşlarınızla vakit geçirmeye onlarla sohbet etmeye devam ediyorsunuz. Tuhaf bir şekilde komşunuz orada olmasına rağmen partinizde iyi vakit geçirebildiğinizin farkına varıyorsunuz. İlk olarak en azından kendi partinizi kaçırmıyorsunuz. İkinci olarak ondan kurtulmaya çalışmadığınız için o da daha sakin, hala rahatsız edici olsa da eskisi kadar kötü değil. Daha sonra komşunuzun daha önce hiç fark etmediğiniz özelliklerini görüyorsunuz. Örneğin keskin de olsa kendine özgü bir mizah anlayışı var ve bu birkaç arkadaşınızın hoşuna bile gitti." Burada danışana davetsiz misafirin kendi olumsuz duygu ve düşünceleri olduğunu, onlarla mücadele ettiği zaman aslında kendi hayatını kaçırdığını ve mücadele etmek yerine onları olduğu gibi kabul ettiği zaman etkisinin zamanla azalacağı mesaj1 verilmektedir.

Danışma sürecinde kullanılan bir diğer teknik kullanılan dilin farkında olmaktır. Bu teknik bilişsel ayrışma için kullanılan tekniklerden biridir. Bu tekniğin kullanım örneklerinden biri "Şu düşünceye sahibim..." ifadesini kul- 
lanmaktır (İzgiman, 2014). “Ben şuyum..." demek yerine "Şu düşünceye sahibim..." demek daha doğru ve çalışlabilir bir ifadedir. Örneğin "Değersizim" demek yerine "Değersiz olduğum düşüncesine sahibim" veya "Zihnimden değersiz olduğuma dair bir düşünce geçti" gibi ifadelerin kullanımı önerilmektedir. Böylece birey düşünceleri ile kendisi arasına bir mesafe koyabilir ve bilişsel birleşmenin önüne geçilmiş olur.

Bir diğer yöntem ise kelime tekrarıdır. Birkaç dakika boyunca bir kelimenin üst üste tekrarlanması o kelimenin anlamını yitirmesine sebep olabilmektedir. Örneğin "kötüyüm" ya da "yağmur" kelimelerinin defalarca tekrarlanması yoluyla bu anlamını kaybetme süreci deneyimlenebilmektedir (Ögel, 2012).

Danışma sürecinden kullanılan başka bir yöntem ise olumsuz duygu ve düşüncelere isim takmaktır. Bu yöntemin amacı olumsuz duygu ve düşüncelere Ali, Ayşe, misafir gibi isimler takılarak bunları somutlaştırmaktır. Böylelikle sorun dışsallaştırıldığı için mücadele edilebilirliği artmaktadır (İzgiman, 2014).

\section{Danışman-Danışan İlişkisi ve Danışmanın Süreçteki Rolü}

$\mathrm{ACT}^{\prime}$ ta terapi sürecinde bir diğer önemli husus ise danışman-danışan ilişkisidir. Her terapi ekolünde danışman ile danışan arasında kurulan terapötik ilişki önemlidir. ACT'ta ise bu ilişki danışma sürecinin olmazsa olmazıdır. Üçüncü dalga davranış terapilerinin, önceki kuşak terapilere göre psikolojik değişim için danışan ile danışman arasındaki ilişkinin hayati bir rol oynadığının daha çok ayırdında olduğu belirtilmektedir (Hayes, 2004). Danışman ile danışan arasındaki eşit ilişkiyi ifade edebilmek adına "iki dağ metaforu" (Hayes, Strosahl ve Wilson, 1999) kullanılmaktadır. Söz konusu metafor kullanılırken danışana "Tehlikeli yerlerle dolu yüksek bir dağı tırmanmak üzeresin. Benim görevim seni izlemek ve ayağının kayabileceği ya da seni incitebilecek noktaları gördüğüm kadarıyla sana bağırarak iletmek. Fakat bunu yapamam, çünkü senin dağının üzerinde dikilmiş duruyor, aşağıya sana doğru bakıyorum. Dağına tırmanmana yardım edebilmem ancak vadinin karşısında kendi dağıma tırmanmam ile mümkün olabilir. Nereye adımını basarsan bunun senin için daha iyi bir yol olabileceğini anlamak için senin dağına 
tırmanmanın tam olarak nasıl bir şey olduğunu bilmek zorunda değilim" denilerek danışana kendisi ile eşit bir ilişki kurulduğu mesajı iletilmeye çalışılmaktadir.

Terapi sürecinde danışman, danışanın yaşamında önem atfettiği alanları araştırarak ve ortaya çıkan alanlarda değer odaklı çalışmalar yaparak danışanın değerlerini keşfetmesine ve anlamasına yardımcı olmaktadır. Danışman, danışanı değerleri doğrultusunda yaşaması konusunda cesaretlendirir, onun hayatında kolaylaştırıcı bir rol oynar ve hiçbir zaman danışanın belirtilerini ortadan kaldırmaya çalışmaz (Harris, 2016; Batten, 2011).

\section{Danışma Sürecinin Aşamaları}

$\mathrm{ACT}^{\prime}$ 'n terapi sürecinin aşamalarına genel yapılandırılmış bir çerçeveden bakılacak olursa söz konusu çerçeve; kendindelik egzersizleri, bir önceki seansın gözden geçirilmesi, temel müdahaleler ve ev ödevi şeklindeki dört yapıdan oluşmaktadır (Harris, 2016). Kendindelik egzersizleri danışanın şimdiki ana dair farkındalığını arttırmaya yöneliktir ve danışanları duyuşsal olarak seansa hazırlamaya yardımcı olmaktadır. Bir önceki seansın gözden geçirilmesi ise verilen ev ödevlerinin gözden geçirilmesine olanak sağlamanın yanı sıra danışanın odakta kalmasına yardım etmesi bakımından önemlidir. Temel müdahaleler ise danışmanın herhangi bir protokol takip edip etmemesine göre şekillenmektedir. Bunun yanı sıra danışmanın protokolünü uygulama konusunda katı olmaması ve seanslarda ortaya çıkabilecek durumlara karşı esnek bir tutum sergilemesi oldukça önemlidir. Ev ödevi, terapi sürecinin en önemli bileşenlerinden biridir. Ev ödevi verilmeden önce, verilecek ödevin mantığı, nasıl yapılacağı konusunda danışan bilgilendirilmeli; henüz içselleştirilmediği düşünülen değerler ile ilgili ödevler verme konusunda danışman ısrarcı bir tutum takınmamalıdır (Terzi ve Tekinalp, 2013; Harris, 2016).

\section{Kabul ve Adanmışlık Terapisinde Kullanılan Değerlendirme Araçları}

Kabul ve Adanmışlık Terapisi yaklaşımının psikopatolojiye belirtilerden ziyade süreçler üzerinden bakması, değerlendirme araçlarının daha çok süreçler üzerinden geliştirilmesini sağlamaktadır (Yavuz, 2015). ACT sürecinde en 
sık kullanılan değerlendirme araçlarından biri geçerlik ve güvenirlik çalışması Yavuz ve arkadaşları (2016) tarafından gerçekleştirilen Kabul ve Eylem Formu (The Acceptance and Action Questionnaire, AAQ) II'dir. 7'li likert tipte 7 maddeden oluşan Kabul ve Eylem Formu yaşantısal kaçınma ve psikolojik katılığın değerlendirilmesinde kullanılmaktadır.

ACT sürecinde kullanılan bir diğer değerlendirme aracı ise Bilişsel Birleşme (Cognitive Fusion) Ölçeğidir. Bilişsel Birleşme Ölçeği 7'li likert tipte 7 maddeden oluşmakta ve bireyin bilişsel birleşme sürecinin değerlendirilmesinde kullanılmaktadır (Gillanders vd. 2014).

Bir başka değerlendirme aracı ise Smout ve arkadaşları (2014) tarafından geliştirilen ve Türk kültürüne uyarlama çalışması Aydın ve Aydın (2017) tarafından gerçekleştirilen Değer Verme Ölçeği (Valuing Questionnaire)'dir. Toplam 10 madde ve "ilerleme" ve "tıkanma" olmak üzere iki alt boyuttan oluşmaktadır.

Kabul ve Adanmışlık Terapisine dayalı geliştirilen değerlendirme araçlarından bir diğeri olan Değer Odaklı Yaşam Ölçeği (Valued Living Questionnaire) ise, ACT sürecinde bireyin yaşamlarını değer odaklı yaşayıp yaşamadıklarını belirlemek üzere Wilson ve Groom (2002) tarafından geliştirilen ve Türk kültürüne uyarlama çalışması Çekici ve arkadaşları (2018) tarafından gerçekleştirilen bir öz-bildirim ölçeğidir. DOYÖ, yaşamın 10 temel alanında değer odaklı yaşamı ölçen iki bölümlü bir ölçektir.

\section{Kabul ve Adanmışlık Terapisinin Etkililiği}

Kabul ve Adanmışlık Terapisi üçüncü dalga davranışçı terapiler içinde en çok etkililik çalışmaları yürütülen yaklaşımdır.

Powers ve arkadaşları (2009) tarafından yapılan ACT'ın etkililiğine ilişkin meta-analiz çalışmasına göre ACT; kontrol grubu, bekleme listesi, plasebo gruplarına ve standart tedaviye açık bir üstünlük sağlarken köklü tedavilere (BDT vb.) herhangi bir üstünlük sağlayamamıştır. ACT ile tedavi edilen danışanlar, kontrol grubundakilerin \%66'sından daha iyi bir ilerleme göstermiştir.

Öst (2014) tarafından gerçekleştirilen ve ACT'ın psikiyatrik bozukluklar, somatik bozukluklar ve iş stresi üzerindeki etkililiğini araştıran bir meta-analiz çalışmasının sonuçlarına göre ACT'ın söz konusu problem alanları üzerinde düşük düzeyde bir etkiye sahip olduğu bulgusuna ulaşılmıştır. Ayrıca 
ACT, bilişsel veya davranışsal tedavilerin birçok farklı türüyle kıyaslanmış ve aralarında düşük düzeyde ve anlamlı olmayan bir farkın olduğu ifade edilmiştir.

A-Tjak ve arkadaşları (2015) tarafından gerçekleştirilen ve 39 kontrollü etkililik çalışmasının dahil edildiği bir başka meta-analiz çalışmasının sonuçlarına göre ACT, tedavi sonrası ve izleme çalışmalarında kontrol gruplarına, bekleme listesine, psikolojik plasebo grubuna ve standart tedaviye üstünlük sağlamıştır. Ayrıca ACT, ikincil kazanımlar, yaşam doyumu/kalitesi ve süreç ölçümleri bakımından da kontrol grubuna göre daha üstündür. Bunun yanı sıra ACT, BDT gibi diğer köklü tedavi yaklaşımları ile kıyaslandığında aralarında anlamlı bir fark olmadığı tespit edilmiş; kaygı bozuklukları, depresyon, bağımlılık ve somatik sağlık problemlerinin tedavisinde ACT'ın bu köklü tedaviler kadar etkili olduğu sonucuna varılmıştır.

Bai ve arkadaşları (2019) tarafından ACT'ın depresyon üzerindeki etkisini araştırmak üzere gerçekleştirilen, 18 kontrollü etkililik çalışmasının dahil edildiği meta-analizi çalışmasında, ACT'ın kontrol grubuna göre depresyonun anlamlı düzeyde azaltılmasını sağladığı bulgusuna yer vermiştir.

Yıldız (2019) tarafından ACT'ın psikoz tedavisindeki etkililiği üzerine gerçekleştirilen meta-analiz çalışmasının sonuçlarına göre ACT'ın, psikotik bozukluklarda görülen depresyon, kaygı ve halüsinasyonlar üzerinde etkili olduğu sonucuna varılmıştır.

Kang, Hwang ve Jun (2019) tarafından ACT'ın kronik ağrı hastaları üzerindeki etkililiğini araştırmak üzere gerçekleştirilen çalışmada, $\mathrm{ACT}^{\prime}$ ın acı, acının kabulü, kaygı, depresyon ve yaşam kalitesi üzerinde etkili olabileceği belirtilmiştir.

Bütün bu araştırmalar doğrultusunda Kabul ve Adanmışlık Terapisi'nin depresyon, kaygı, bağımlılık, kronik ağrı, psikotik bozukluklar vb. çeşitli problem alanları üzerinde etkili olduğu söylenebilmektedir. Öte yandan terapinin gücünün ve bilimselliğinin arttırılması bağlamında yapılacak kontrollü etkililik çalışmalarına ihtiyaç duyulduğu söylenebilmektedir.

\section{Kabul ve Adanmışlık Terapisi Eğitimi}

Kabul ve Adanmışlık Terapisi eğitimleri başta kuramın kurucularından olan Steven C. Hayes'in (https://act.courses/course-closed/) kendisi olmak üzere 
dünyanın birçok yerinde birçok eğitimci tarafından online veya yüz yüze olmak üzere verilebilmektedir. Ülkemizde ise ACT eğitimleri, Bağlamsal Davranış Bilimleri Derneği (http://www.baglamsalbilimler.org) ve Kognitif Davranışçı Terapileri Derneği (https://kdtd.org.tr/) gibi dernekler üzerinden yürütülmektedir. Öncelikle katılımclara temel eğitim verilmekte sonrasında ileri eğitimler ve süpervizyonlar ile süreç devam etmektedir.

\section{Kabul ve Adanmışlık Terapisine Yöneltilen Eleștiriler}

Kabul ve Adanmışlık Terapisi, diğer üçüncü dalga terapiler gibi ortaya çıtığı günden bu yana birtakım eleştirilere maruz kalmaktadır. Bu bölümde $\mathrm{ACT}^{\prime} \mathrm{a}$ yöneltilen eleştirilere yer verilecektir.

ACT'a ilk sert eleştiri Corrigan (2001) tarafından yapılmıştır. Söz konusu çalışmasında Corrigan, üçüncü dalga davranışçı yaklaşımlarını bilimsel yayın sayılarının yetersiz olması bakımından eleştirerek söz konusu yaklaşımların ellerindeki bilimsel verinin ötesinde yorumlarda bulundukların ifade etmiştir. Bu makale yayımlandıktan sonra uzun yıllar boyunca Corrigan, çeşitli konularda ACT araştırmacılarına yardımcı olmuştur (Hayes, t.y.)

Hofmann ve Asmundson (2008) tarafından yürütülen çalışmada ACT'ın ve diğer farkındalık temelli terapilerin Bilişsel Davranışç Terapiyle aynı şey olduğunu ifade etmiş ve duygudurum bozukluklarının tedavisinde BDT'den daha etkili olduğu iddiasını yalanlamıştır. Üçüncü dalga yaklaşımların gerçekten "üçüncü dalga" denebilecek kadar ellerinde veri olmadığını vurgulayan makalede Metakognitif Terapi'nin kurucusu Adrian Wells ve Diyalektik Davranışç Terapi'nin kurucusu Marsha Linehan ile kişisel görüşmeler yapıldığından ve bu görüşmelerde Wells ve Linehan'ın kendi yaklaşımlarını üçüncü kuşak davranış terapileri arasında görmediklerini aksine BDT'nin bir uzantısı veya BDT'nin kabul stratejilerini içeren bir formu olduğunu ifade ettiklerinden bahsedilmiştir.

Hofmann (2008) bir başka makalesinde Hayes'in (2004) "üçüncü dalga" tabirini eleştirmiş ve ACT'ın BDT'nin yerini alacak bir terapi olmadığını ifade etmiştir. ACT'ın “duygusal kaçınma, bilişsel içeriğe aşırı gerçek tepki ve davranış değişikliği için taahhütte bulunma ve sürdürememe" gibi temel amaçlarının Gestalt yaklaşımı gibi birçok eski insancıl terapi ve bütüncül yaklaşımla benzer olduğunu söylemiştir. Bunun yanı sıra ACT'ın 1928 yılında 
Shoma Morita isimli Japon bir psikiyatrist tarafından geliştirilen Morita Terapi ile çok fazla benzerliğe sahip olduğunu ve kavramlarının neredeyse birebir aynı olduğunu vurgulamış ve bu benzerlikleri makalesinde ele almıştır.

Kabul ve Adanmışlık Terapisi'ne en sert eleştirilerde bulunan Hofmann, günümüzde Steven C. Hayes ile birlikte süreç temelli terapiler üzerine akademik çalışmalar yapmakta ve eğitimler vermektedir.

\section{Tartışma ve Sonuç}

İnsan, doğası gereği acıdan kaçma ve kendisine iyi hissettiren, onu mutlu eden şeylerin peşinde koşma eğilimi göstermektedir. Bu eğilim günümüzde her türlü kanalla beslenerek adeta insanları mutluluğun kölesi haline getirmektedir. Hâlbuki insanın hayatında yalnızca olumlu duyguların olması mümkün değildir ve acı insan hayatının kaçınılmaz bir unsurudur. İşte bu noktada önemli olan insanın bu acı verici olay ya da durumlar karşısında nasıl bir tutum sergilediğidir. Acıyı reddetme, ondan kaçınma fiziksel durumlar veya olaylar için işe yarar görünse de psikolojik, içsel durumlarda bu stratejiler ne yazık ki işe yaramamaktadır. Zira insan, nereye giderse gitsin, ne kadar uzaklaşmaya çalışırsa çalışsın zihni beraberinde o acıyı da götürecektir. Üstelik kaçmaya çalıştığı o acı verici duygu ve düşünceler o kaçmaya çalıştıkça artacak ve paradoksal bir etki gösterecektir. Kabul ve Adanmışlık Terapisi işte tam da bu noktada bireyi kontrolü dışında gerçekleşen acı verici duygu, düşünce ve yaşantıları kabul etmeye; değerlerinin farkına varmaya ve değerleri doğrultusunda hayatını zenginleştirecek davranışları sürdürmeye adanmış olmaya davet etmekte ve anlamll, dolu dolu bir yaşam sürmesinde ona yardımc olmaya çalışmaktadır.

Güneşin Doğu'dan doğduğunun ve yüzünü Doğu'ya dönmenin ne kadar önemli olduğunun son yıllarda farkına varan üçüncü dalga davranış terapilerinden biri olan $\mathrm{ACT}$, mensup olduğu üçüncü kuşağın diğer terapilerinde de olduğu gibi farkındalık temelli ve bağlamsal bir terapi yaklaşımıdır. İkinci dalga davranış tedavilerinin (örneğin BDT) kaçırdığı en önemli noktalardan biri bireyi bulunduğu tarihsel ve durumsal bağlamından ayrı değerlendirerek belli semptomlara sahip bireylere anahtar kognisyonlar üzerinden belirli tedaviler uygulayarak sağaltımı gerçekleştirmeye çalışmasıdır. Zira hiçbir insan kendi bağlamından bağımsız değerlendirilemez. Bireyin sahip olduğu olumsuz duygu ve düşünceler ele alınırken o kişinin tarihsel ve durumsal 
bağlamı mutlaka dikkate alınmalı ve buna göre bir tedavi planı oluşturulmalıdır. ACT'ta müdahalenin amacı bireyin olumsuz duygu ve düşüncelerini değiştirmek değil, bireyin bu duygu ve düşüncelerle arasındaki ilişkiyi değiştirmektir. İlişki değiştiğinde belirtilerin azalması olası bir sonuçtur ve bu durum ACT tedavisinin ikincil bir getirisidir.

ACT'ın insanın dil ve bilişine yaptığ vurgu da son derece değerlidir. Zira insan, diğer tüm canlılardan farklı olarak fiziksel ilişkilendirmenin yanı sıra soyut ilişkilendirme yeteneğine de sahiptir. Böylece insan zihni kurduğu karşılıklı ve kombinasyonel ilişkilendirmeler vasıtasıyla en güzel bir anını bile acı dolu bir hale getirebilmektedir. İnsanların kullandıkları dili onların acılarının kaynağı olarak gören $\mathrm{ACT}$, danışma sürecinde danışanın kullandığı dile çeşitli yöntemlerle müdahale ederek daha yapıc ve olumlu bir dil kullanmalarına yardımcı olur.

İnsanın kendine dair farkındalık kazanması son derece önemlidir. Özellikle bireyin kendi değerlerini keşfetmesi, bu değerler doğrultusunda sürdüreceği yaşamının ilk basamağıdır. Nasıl ki pusulası olmayan bir gemi kaptanı açık sularda yönünü tayin etmede zorlanır ve yolunu kaybederse değerlerinin farkında olmayan birey de yaşam yolcuğunda zorluklarla karşılaşacaktır. ACT, bireyin çıacağı bu uzun yaşam yolculuğunda pusulasını bulmasına yardımcı olmaktadır.

Kayg1, depresyon, kronik ağrı, somatik bozukluklar, iş stresi vb. birçok alanda etkili olduğu kanıtlanan ACT, çocukluktan yaşlılığa kadar tüm gelişim dönemlerine uygulanabilmekte ve yeri geldiğinde önleyici bir hizmet işlevi de görmektedir. Ülkemizde henüz yeni yeni yayginlaşmakta olan ACT'ın özellikle okul psikolojik danışmanları tarafından okullarda kullanımının önemli olduğu düşünülmektedir. Bireysel veya grup formatında gerçekleştirilecek ACT temelli kontrollü etkililik çalışmalarının ve betimsel çalışmaların ulusal alan yazına katkı sağlayacağı düşünülmektedir. 


\title{
EXTENDED ABSTRACT
}

\section{A Review on Acceptance and Commitment Therapy (ACT)}

\author{
* \\ Aykut Kul - Fulya Türk \\ Gaziantep University
}

"Feeling good", always pursuing happiness, the desire to experience positive emotions and avoiding negative emotions have become one of the most basic life goals of people today. However, although it is unlikely to have only positive emotions in a person's life, pain is an inevitable part of human life. At this point, Acceptance and Commitment Therapy (ACT), as can be understood from its name, tries to help them live a meaningful and full life by encouraging individuals to accept things beyond their personal control and to be determined to continue their life-enriching behavior.

From this point of view, Acceptance and Commitment Therapy means not to see the negative emotions and thoughts on individuals occupying their minds and even affecting their bodies; instead of fighting these feelings and thoughts, it aims to teach them how to deal with different and new ways and to help them live in the current main focus by accepting these experiences as they are, so to speak, by perceiving them as "guests" (Eifert \& Forsyth, 2005). When the individual can accomplish all this, he / she will be able to reach psychological flexibility (Hayes, Strosahl and Wilson, 1999). The aim of this study is to analyze Acceptance and Commitment Therapy from a general perspective.

With Watson (1925), it is stated that three generations (waves) are included in the history of Behavioral Therapy approaches, which have passed almost a century since their foundations were laid (Hayes, 2004). When we look at the applications in the first wave behavioral therapies, the focus is on the behaviors that can be observed, and it is aimed to make changes on these behaviors using methods such as classical conditioning and operant learning (Vatan, 2016). By the late 1960s, new behaviorist theorists stated that it was not enough to focus only on observable behaviors, and that cognitions were 
important in the relationship between stimulus and response. Thus, the second wave of Behavioral Therapies emerged. Rational Emotive Behavioral Therapy of Albert Ellis (1962) and Cognitive Therapy of Beck (1964) are the most known second wave of behavioral therapy. Second-wave behavioral therapies (especially cognitive behavioral therapy) are criticized for ignoring emotions as they focus more on controlling thoughts and beliefs (Izgiman, 2014). In line with these criticisms, third wave approaches, which attach importance to the individual's inner lives and focus on concepts such as insight, awareness and acceptance, have begun to emerge. Among the third wave approaches are Dialectical Behavior Therapy (Linehan, 1993), Metacognitive Therapy (Wells, 2000), Mindfulness-Based Cognitive Therapy (Segal, Williams and Teasdale, 2002), Acceptance and Commitment Therapy (Hayes and Strosahl, 2004) and Emotion Regulation Therapy (Berking and Whitley, 2014).

It is stated that among the third wave behavioral therapies, the most prominent approach in terms of both prevalence and scientific data is Acceptance and Commitment Therapy (ACT) (Hayes, 2004). Acceptance and Commitment Therapy is a present focused, mindfulness-based approach that comes from a radical behavioral school, whose effectiveness is proven with scientific data, and its philosophy is based on the relationship between language and cognition (Hayes, Strosahl, and Wilson, 1999). The main purpose of Acceptance and Commitment Therapy is to transform the relationship between the individual and compulsive thoughts or emotions into a new structure. Unlike Cognitive Behavioral Therapy, ACT aims to change the relationship it has with that thought, rather than changing the thought that forces the individual and negatively affects his life. In the new structure, it is the main purpose to look at and understand them more than to get away from the thoughts or feelings that are thought to cause problems. Consequently, the reduction of symptoms is a secondary benefit of focusing on thoughts and emotions rather than ACT's main purpose (Harris, 2006).

Acceptance and Commitment Therapy basically consists of three processes (Harris, 2016; Terzi and Tekinalp, 2013):

$\mathrm{A}=$ Acceptance of your thoughts and feelings and be present

$\mathrm{C}=$ Choose $\mathrm{a}$ valued direction

$\mathrm{T}=$ Take action 
Psychological flexibility is defined as the situation where the individual is determined to behave in contact with the moment and behave in line with their values by approaching their inner lives with attention and clarity. The main purpose of the ACT process is to increase the client's psychological flexibility.There are six basic concepts that provide the psychological flexibility of the individual. These are: being in the moment, acceptance, cognitive defusion, self as a context, values and value-oriented actions.

Being in the moment means being in contact with the present time, being here and now, being aware and conscious of what is currently being experienced, without being lost between thoughts. For Acceptance and Commitment Therapy, it is very important to raise awareness of the client regarding the current moment.

Acceptance is one of the main processes of ACT. Acceptance is to create a space in the mind of the person, his painful feelings, experiences, memories and impulses, and to ensure that they are there without struggling with them by providing a space for all of them in the area he creates. The meaning of loving these negative, painful experiences or asking them should not be deducted from this.

Cognitive defusion refers to individuals' ability to define emotions, thoughts and memories as facts about themselves and their environment, and to define them only as a phenomenon like inner life. In other words, it is the distance between thought and the person who thinks that thought (Walser \& Westrup, 2007).

Self as a context is the experience of acceptance without judgment, and the experience of being here and now as it is. Observing the contextual self is described as "pure awareness" (Harris, 2016).

Values represent what a person wants to do in life, to represent and how to be one, and how he wants to behave accordingly (Hayes, Strosahl and Wilson, 1999). Just as the individual wants to be remembered as the end of his life, his values will be in this direction (Ögel, 2015).

Value-oriented actions are effective actions driven by the values of the person. In the treatment process, it is aimed to transform values into sustainable and value-oriented behaviors (Harris, 2016).

ACT utilizes many different techniques in the counseling process such as metaphors, awareness of the language used, word repetition and naming negative emotions and thoughts. Metaphor is an important treatment tool in the 
ACT process. Among the most commonly used metaphors are metaphors such as "hands metaphor" and "party metaphor". Another important technique is to be aware of the language used. This technique is one of the techniques used for cognitive defusion. For example, instead of saying "I am worthless", it is suggested to use expressions such as "I have the idea that I am worthless" or "I have thought that I am worthless". Another method is word repetition. Repeating a word for several minutes may cause that word to lose its meaning. For example, the process of losing this meaning can be experienced by repeatedly repeating the words "I am bad" or "rain" (Ögel, 2012).

ACT is an approach among third wave behavioral therapies which has the most effectiveness studies When these effectiveness studies are examined, ACT's depression, anxiety disorders, psychotic disorders, chronic pain, somatic disorders, work stress, acceptance of pain, quality of life etc. appears to be effective in many areas (Powers et al., 2009; Öst, 2014; A-Tjak et al., 2015; Bai et al., 2019; Kang, Hwang and Jun, 2019; Yıldız, 2019).

As a result, ACT, which has proven to be effective in many areas such as anxiety, depression, chronic pain, somatic disorders, work stress, etc., can be applied to all developmental periods from childhood to old age and also acts as a preventive service when it is appropriate. It is considered that the use of $\mathrm{ACT}$, which has just become widespread in Turkey, is particularly important in school psychological counselors. It is thought that ACT-based controlled effectiveness studies and descriptive studies to be carried out in individual or group format will contribute to the national literature.

\section{Kaynakça / References}

A-tjak, J. G., Davis, M. L., Morina, N., Powers, M. B., Smits, J. A., ve Emmelkamp, P. M. (2015). A meta-analysis of the efficacy of acceptance and commitment therapy for clinically relevant mental and physical health problems. Psychotherapy and Psychosomatics, 84(1), 30-36.

Aydın, Y., ve Aydın, G. (2017). Değer verme ölçeği (DVÖ)'ni Türk Külttürüne uyarlama çalışması. Abant İzzet Baysal Üniversitesi Eğitim Fakültesi Dergisi, 17(1), 64-77.

Bach, P. A. ve Moran, D. J. (2008). ACT in practice case conceptualization in Acceptance and Commitment Therapy. Oakland, CA: New Harbinger Publications. 
Bai, Z., Luo, S., Zhang, L., Wu, S., ve Chi, I. (2019). Acceptance and commitment therapy (act) to reduce depression: A systematic review and meta-analysis. Journal of Affective Disorders, 260, 728-737.

Batten, S. (2011). Essentials of acceptance and commitment therapy. California: Sage Publications.

Beck, A. T. (1970). Cognitive therapy: Nature and relation to behavior therapy. Behavior Therapy, 1(2), 184-200.

Berking, M., ve Whitley, B. (2014). Emotion Regulation: Definition and Relevance for Mental Health. Affect regulation training içinde (ss. 5-17). New York: Springer.

Blackledge, J. T. ve Barnes-Holmes, D. (2009). Core processes in acceptance and commitment therapy. J. T. Blackledge, J. Ciarrochi \& F. P. Deane (Ed.). Acceptance and Commitment Therapy: contemporary theory research and practice içinde (s. 4158). Australia: Australian Academic Press.

Bolderston, H. (2013). Acceptance and commitment therapy: Cognitive fusion and personality functioning. (Doctoral Dissertation) University of Southampton, Faculty of Social and Human Sciences, School of Psychology.

Eifert, G. H. ve Forsyth, J. P. (2005). Acceptance and commitment therapy for anxiety disorders. Oakland, CA: New Harbinger Publications.

Gillanders, D. T., Bolderston, H., Bond, F. W., Dempster, M., Flaxman, P. E., Campbell, L., ... , Masley, S. (2014). The development and initial validation of the cognitive fusion questionnaire. Behavior Therapy, 45(1), 83-101.

Harris, R. (2016). Kabul ve kararllık terapisi. ACT'i kolay öğrenmek: ilkeler ve ötesi için hızh bir başlangıc. H T. Karatepe ve K. Fatih Yavuz (Çev. Ed.). İstanbul: Litera Yayınclik.

Hayes, S. C., Barnes-Holmes, D. ve Wilson, K. G. (2012). Contextual behavioral science: Creating a science more adequate to the challenge of the human condition. Journal of Contextual Behavioral Science, 1(1-2), 1-16. DOI: 10.1016/j.jcbs.2012.09.004

Hayes, S. C. (2004). Acceptance and commitment therapy, relational frame theory, and the third wave of behavioral and cognitive therapies. Behavior Therapy, 35(4), 639-665.

Hayes, S. C. (2015). Analytic goals and the varieties of scientific contextualism. The Act in Context içinde (s. 126-142). London: Routledge.

Hayes, S. C. (t.y.). Criticisms of ACT. 17.01.2020 tarihinde.https://contextualscience.org/criticisms of act adresinden erişilmiştir. 
Hayes, S. C. ve Brownstein, A. J. (1986). Mentalism, behavior-behavior relations and a behavior analytic view of the purposes of science. The Behavior Analyst, 1, 175-190.

Hayes, S. C. ve Smith, S. (2005). Get out of your mind and into your life: the new Acceptance and Commitment Therapy. Oakland, CA: New Harbinger Publications.

Hayes, S. C., Strosahl, K. D., Bunting, K., Twohig, M. ve Wilson, K. G. (2004). What is acceptance and commitment therapy. S. C. Hayes ve K. D. Strosahl (Ed.). A Practical Guide to Acceptance and Commitment Therapy içinde (s. 1-30). New York: Springer. DOI 10.10071978-0-387-23369-7

Hayes, S. C., ve Strosahl, K. D. (Ed.). (2004). A practical guide to acceptance and commitment therapy. Berlin: Springer Science \& Business Media.

Hayes, S. C., Barnes-Holmes, D. ve Roche, B. (Ed.). (2001). Relational frame theory: A post-skinnerian account of human language and cognition. New York: Plenum Press.

Hayes, S.C., Strosahl, K. ve Wilson K. G. (1999) Acceptance and commitment therapy: An experiential approach to behavior change. New York: Guilford.

Hayes, S. C., ve Hofmann, S. G. (2017). The third wave of cognitive behavioral therapy and the rise of process-based care. World Psychiatry, 16(3), 245.

Hayes, S. C., ve Hofmann, S. G. (Ed.). (2018). Process-based CBT: The science and core clinical competencies of cognitive behavioral therapy. Oakland, CA: New Harbinger.

Hayes, S. C., Hofmann, S. G., Stanton, C. E., Carpenter, J. K., Sanford, B. T., Curtiss, J. E., ve Ciarrochi, J. (2019). The role of the individual in the coming era of process-based therapy. Behaviour Research and Therapy, 117, 40-53.

Hofmann, S. G. (2008). Acceptance and commitment therapy: new wave or morita therapy?. Clinical Psychology: Science and Practice, 15(4), 280-285.

Hofmann, S. G., ve Asmundson, G. J. (2008). Acceptance and mindfulness-based therapy: New wave or old hat?. Clinical Psychology Review, 28(1), 1-16.

Hofmann, S. G., ve Hayes, S. C. (2019). The future of intervention science: Processbased therapy. Clinical Psychological Science, 7(1), 37-50. https://stevenchayes.com/about/ adresinden erişilmiştir.

İzgiman, S. (2014). Kabullenme ve kararlılık terapisi. A. N. Canel (Ed.). Terapide Yeni Ufuklar: Modern, Postmodern ve Kısa Terapiler içinde (s. 97-115). İstanbul: Pinhan Yayıncilı.

Linehan, M. M. (1993). Skills training manual for treating borderline personality disorder. New York: Guilford Press. 
Pearson, A. N., Heffner, M. ve Follette, V. (2010). Acceptance and Commitment Therapy for Body Image Dissatisfaction. Oakland, CA: New Harbinger Publications.

Powers, M. B., Vörding, M. B. Z. V. S., ve Emmelkamp, P. M. (2009). Acceptance and commitment therapy: A meta-analytic review. Psychotherapy and Psychosomatics, 78(2), 73-80.

Segal, Z., Williams, M., ve Teasdale, J. (2002). Mindfulness-based cognitive therapy for depression: A new approach to preventing relapse: Book review. New York: Guilford Press.

Smout, M., Davies, M., Burns, N., ve Christie, A. M. (2014). Development of the valuing questionnaire. Journal of Contextual Behavioral Science, 3(3). doi: 10.1016/j.jcbs.2014.06.001

Strosahl, K. D. (2004). ACT with multi problem client. S. C. Hayes \& K. D. Strosahl (Ed.). A practical guide to Acceptance and Commitment Therapy içinde (s. 209244). Oakland, CA: New Harbinger.

Terzi, B. E. ve Tekinalp, Ş. I. (2013). Psikolojik danışmada güncel kuramlar. Ankara: Pegem Akademi.

Terzioğlu, M. ve Yavuz, F. K. (t.y.). Ilişkisel çerçeve kuramı (Relational Frame Theory RFT): Bir dil ve bilis teorisi. 11.01.2020 tarihinde http://www.baglamsalbilimler.org/act-rft/rft/ adresinden erişilmiştir.

Törneke, N. (2010). Learning RFT: An introduction to relational frame theory and its clinical application. California: New Harbinger Publications.

Vatan, S. (2016). Bilişsel davranışçı terapilerde üçüncü kuşak yaklaşımlar. Psikiyatride Güncel Yaklaşımlar, 8(3), 190-203.

Walser, R. D. ve Westrup, D. (2007). Acceptance and commitment therapy for the treatment of post-traumatic stress disorder and trauma-related problems. Oakland, CA: New Harbinger Publications.

Watson, J. B. (1925) Behaviorism. New York: Norton.

Wells, A. (2000). Emotional disorders and metacognition: Innovative cognitive therapy. Chichester, UK: Wiley.

Wilson, K. G. ve Groom, J. (2002). The Valued Living Questionnaire (Unpublished document) available from the first author at the Department of Psychology, University of Mississippi, University, MS.

Yavuz, F., Ulusoy, S., Iskin, M., Esen, F. B., Burhan, H. S., Karadere, M. E., ve Yavuz, N. (2016). Turkish version of acceptance and action questionnaire-II (AAQII): A reliability and validity analysis in clinical and non-clinical samples. Klinik Psikofarmakoloji Bülteni-Bulletin of Clinical Psychopharmacology, 26(4), 397-408. 
Yavuz, K. F. (2015). Kabul ve kararlllık terapisi (ACT): Genel bir bakış. Turkiye Klinikleri Journal of Psychiatry Special Topics, 8(2), 21-27.

Yıldız, E. (2019). The effects of acceptance and commitment therapy in psychosis treatment: A systematic review of randomized controlled trials. Perspectives in Psychiatric Care, 56(1), 149-167.

\section{Kaynakça Bilgisi / Citation Information}

Kul, A. ve Türk, F. (2020). Kabul ve adanmışlık terapisi (act) üzerine bir derleme çalışması. OPUS-Uluslararası Toplum Araştırmaları Dergisi, 16(Özel Sayı), 3773-3805, DOI: 10.26466/opus.741907 